\title{
MEASURING CUSTOMER'S SATISFACTION AS A TOOL TO IMPROVE THE QUALITY OF SERVICES IN EGYPTIAN SPAS (SPAS IN CAIRO CITY AS A CASE STUDY)
}

\author{
Soha Bahgat Farag \\ Assistant Professor \\ The Higher Institute of Specifics Studies - Giza
}

\begin{abstract}
In the recent years, several countries have turned to a new area of tourism - health and wellness. This niche area explores the intersection of healthcare services and tourism packages, and often depends on local factors such as high-quality health services, cost competitiveness, climate conditions, or specific geographical resources advantages.

Egypt as one of the most important touristic countries in the region has a long tradition of bathing associated with the hammams Turkish baths and pharaonic ones (AmCham Egypt 2012). Early indications are that Egyptians were the first to discover the potential of water and essential oils for therapeutic purposes. Remedial treatments and bath spas have been around for thousands of years, with well-being philosophies dating back as far as 7000 BC when the fatty oils of olive and sesame were thought to have been combined with fragrant plants to create the original Neolithic ointments. (http://www.thespatraveller.com/Articles/The-history-ofspas.htm).

In Egypt, the market and research analysis companies forecast a compound annual growth rate of 5\% through 2016, when sales are expected to exceed EGP 1.2 billion. Previous studies have discussed the Spa industry. However, customer service-related research from the perspectives of customers and operators is rare.

From the outset, it would be useful to understand the relation between the quality of services in Spa and the customer loyality. To assess the reliability of the measure in this study, Cronbach's coefficient alpha was used. Cronbach's alpha is the most accepted formula for assessing reliability of a measurement with multi-point items.
\end{abstract}

Keywords: Wellness - Spa - wellness tourism - customer Satisfaction -service quality.

\section{Background}

There is no rigorously developed definition of wellness. According to Smith and Puczkó (2009) wellness is a complex concept, containing elements of lifestyle ; physical, mental, and spiritual well-being; and one's relationship with oneself, others, and environment. Konu et al. (2010) also contended that wellness includes various related concepts, such as well-being, happiness, quality of life, holistic practice, and spiritual beliefs. Nevertheless, wellness is relative, subjective, and perceptual (Adams, 
2003). Messerli and Oyama (2004) viewed wellness as a way of life to create a healthy body, soul, and mind through acquired knowledge and positive interventions.

Accordingly, Wellness is a multi-dimensional concept, which may include physical, mental, spiritual, sexual, educational, occupational, economic, political, social, cultural, ethical, environmental and existential attributes.

Wellness tourism is regarded as a subcategory of health tourism (Mueller and Lanz Kaufmann, 2001; Nahrstedt, 2004). Several researchers have classified health tourism into medical tourism and wellness tourism, medical tourism aims to treat an illness or facilitate physical recovery following surgery through stays in a hospital or medical center to receive care, whereas wellness tourism aims to provide relaxation, leisure, and an escape from daily stresses to disease-free tourists through stays in health spa resorts (Harahsheh, 2002 ; Mueller and Lanz Kaufmann, 2001).

Wellness tourism has grown in over the last 10-15 years. Still only hazily understood by most costumers, in popular usage the term can be applied to any thing that makes one feel good or that is healthy (the global wellness tourism economy, 2013).

Wellness tourism represents about 6\% (524.4 million) of all domestic and international trips, it accounts for about $14 \%$ ( $\$ 438.6$ billion) of all domestic and international tourism expenditures, and it is projected to grow by more than $9 \%$ per year through 2017, nearly 50\% faster than overall global tourism.

Wellness tourism generates 11.7 million direct jobs, delivering \$1.3 trillion of global economic impact (1.8\% of global GDP in 2012) (the global wellness tourism economy 2014)

Spa tourism is recognized as the most renowned form of wellness tourism, and the term is often interchangeable with wellness tourism (Smith and Puczkó, 2009). Almost all wellness tourism services include some health orientated services referred to as "spa treatment" (Erfurt-Cooper and Cooper, 2009). Although different providers define "spa" differently, the desire remains to promote health and happiness. The emergence of the spa industry that integrates industry, customs, and therapeutic methods is a recent global phenomenon. The emergence of a global spa industry is considered a natural response to the human desire for wellness in the context of the evolution of consciousness, globalization, and various global crises (Cohen, 2008). Joppe (2010) argued that the spa industry would be required to place a greater emphasis on learning by inviting knowledgeable speakers from conventional and complementary fields and alternative medicine fields to educate consumers wishing to make informed decisions regarding their health. The various services of spas are categorized according to the available regional resources, including natural resources such as therapeutic water, climate, mud, and caves for meditation. Spa offerings in Asia are mainly built around traditional and spiritual massages and hot spring therapies (Puczkó and Bachvarov, 2006). Currently, spa therapies have been redeveloped, consolidated, and branded to create a novel global industry from related industries. The emergence of spas has also added a new standard icon to global luxury hotels and resorts. While the global spa industry is still evolving, it is apparent that the industry is beginning to embrace wellness as part of its core business (Cohen, 2008). 
Spa is a core business within wellness tourism and accounts for a significant portion of the wellness economy.

In 2012, spa tourism represented a $\$ 179.7$ billion market, with 224,9 million spa and $41 \%$ of the global tourism expenditures (the global wellness tourism economy, 2013).

Middle East and Africa are the smallest regions for wellness tourism in terms of both number of trips and expenditures (table1).

According to final static of Middle East wellness tourism economy the arrival trips for wellness tourism in Egypt is 939.8 thousands.

Table 1. number of trips and expenditures in Middel East \&Africa

\begin{tabular}{|c|c|c|c|c|c|c|}
\hline \multicolumn{2}{|c|}{ Economic Impact } & \multirow[b]{2}{*}{$\begin{array}{l}\text { Market Size } \\
\text { Wellness } \\
\text { Tourism } \\
\text { Receipts/ } \\
\text { Expenditures } \\
\text { (\$ millions) }\end{array}$} & \multicolumn{4}{|l|}{ Trips } \\
\hline $\begin{array}{l}\text { Wellness } \\
\text { Tourism } \\
\text { Economic } \\
\text { Impact } \\
\text { (\$ } \\
\text { millions) }\end{array}$ & $\begin{array}{l}\text { Wellness } \\
\text { Tourism } \\
\text { Direct } \\
\text { Employment } \\
\text { (jobs) }\end{array}$ & & $\begin{array}{l}\text { Domestic } \\
\text { Wellness } \\
\text { Trips } \\
\text { (000s) }\end{array}$ & $\begin{array}{l}\text { Intl./ Inbound } \\
\text { Wellness } \\
\text { Arrivals } \\
(000 s)\end{array}$ & $\begin{array}{l}\text { Total } \\
\text { Wellness } \\
\text { Arrivals/ } \\
\text { Trips } \\
\text { (000s) }\end{array}$ & \\
\hline$\$ 4,601.2$ & 75,671 & $\$ 1,487.3$ & 823.8 & 665.9 & $1,489.7$ & South Africa \\
\hline$\$ 3,042.7$ & 9,133 & $\$ 1,410.4$ & 175.8 & 603.6 & 779.4 & UAE \\
\hline$\$ 3,241.0$ & 14,387 & $\$ 973.2$ & 368.7 & 262.1 & 630.8 & Israel \\
\hline$\$ 1,775.4$ & 80,247 & $\$ 824.0$ & 373.7 & 464.2 & 837.9 & Morocco \\
\hline$\$ 1,544.9$ & $\mathbf{5 6 , 5 5 5}$ & $\$ 702.1$ & 346.4 & 593.4 & 939.8 & Egypt \\
\hline$\$ 1,218.4$ & 15,809 & $\$ 327.6$ & 67.4 & 271.9 & 339.3 & Jordan \\
\hline$\$ 526.3$ & 16,872 & $\$ 252.1$ & 127.4 & 354.5 & 481.9 & Tunisia \\
\hline$\$ 420.9$ & 2,598 & $\$ 175.4$ & 173.2 & 48.0 & 221.2 & Saudi Arabia \\
\hline$\$ 347.6$ & 2,407 & $\$ 152.0$ & 25.7 & 52.3 & 78.1 & Oman \\
\hline$\$ 374.9$ & 6,637 & $\$ 146.5$ & 3.6 & 58.5 & 62.2 & Seychelles \\
\hline$\$ 358.5$ & 3,869 & $\$ 132.6$ & 8.3 & 33.3 & 41.7 & Lebanon \\
\hline$\$ 315.0$ & 2,813 & $\$ 125.4$ & 0.0 & 180.0 & 180.0 & Bahrain \\
\hline
\end{tabular}

-The global wellness tourism economy, 2013

\section{Statement of The Problem}

In the Spa industry a customer service experience can alter a customer's entire perception of the organization, especially when it matches the customer's expectation. No previous empirical studies have been conducted on the relation between the customer satisfaction and the quality of services /products in the spa industry in Cairo region. This study will focus on how could the quality of services offered in Cairo Spas through a series of activities designed to enhance the level of customer satisfaction, that is, customers' feeling that a product could lead to the ability to obtain profits and gain the customer loyalty to increase the demand on wellness tourism in Egypt. 


\section{Research Objectives}

The Spa industry suffers from imprecision regarding its basic concept. In this paper we will focus on measuring customer's satisfaction to improve the quality of service in spas at Cairo region as a tool to increase customer loyalty.

\section{Research Hypothesis}

A hypothesis defines an expected relationship between variables (based on causal relationships in the theoretical model), which can be empirically tested. The hypothesis in this research can be expressed as:

1. There is relationship between product and service quality in Egyptian spas and achieving customers' satisfaction.

2. There is relationship between customer satisfaction in Egyptian spas and customer loyalty.

\section{Methodology}

This study was conducted as an Empirical research method that descriptive analytical surveying used for observations or gathering data in order to answer particular research hypothesis.

A sample of 400 questionnaires has been distributed on 15 five stars hotels in great Cairo.

To assess the reliability of the measure in this study, Cronbach's coefficient alpha was used. Cronbach's alpha is the most accepted formula for assessing reliability of a measurement with multi-point items.

Reliability alone is not sufficient to consider that an instrument is adequate. Therefore, validity is required to validate the constructs of this study. The overall reliability and validity coefficient of each instrument are presented in the following table.

Table 2: Coefficient of reliability and validity of questionnaire

\begin{tabular}{|l|l|l|l|}
\hline Instrument & $\begin{array}{l}\text { No. of } \\
\text { items }\end{array}$ & $\begin{array}{l}\text { Cronbach's Alpha } \\
\text { Coefficient }\end{array}$ & Validity \\
\hline Product quality & 5 & 0.716 & 0.846 \\
\hline Service quality & 3 & 0.797 & 0.892 \\
\hline Customer satisfaction & 3 & 0.573 & 0.756 \\
\hline Customer loyalty & 4 & 0.633 & 0.795 \\
\hline Overall Total Scale & 15 & 0.837 & 0.914 \\
\hline
\end{tabular}

Reliability analysis results cleared that the overall total scale were above $(0.60)$ for all questionnaire items. On the other hand, the validity coefficient of the questionnaire was 0.914 . Since most of the constructs of the questionnaire had a relatively accepted 
scores of reliability and validity coefficient, it can be assured that the used items included in the questionnaire are valid to measure what it supposed to measure.

In this study the method of collecting and gathering data from a part of population was used by the questionnaire structured.

\section{Literature Review}

Meanings. Wellness. Wellness is an active process through which people become aware of, and make choices toward, a more successful existence (National wellness institute).

Wellness means a healthy balance of the mind, body and spirit that results in an overall feeling of wellbeing. This is a way of life oriented toward optimal health and wellbeing in which the body, mind and spirit are integrated by the individual to live more fully within the human and natural community (Behrens, A, 2007).

Meanings: wellness tourism: The University of Berne's Research Institute for Leisure and Tourism defines wellness tourism as 'the sum of all the relationships and phenomena resulting from a journey and residence by people whose main motivation is to preserve or promote their health.' It requires a comprehensive service package comprising physical fitness, beauty care, healthy nutrition, and relaxation....etc. (Muller and Kaufmann 2001, P. 8).

Spa: The International Spa Association (ISPA) defines Spas as "places devoted to overall well-being through a variety of professional services that encourage the renewal of mind, body and spirit". (http://experienceispa.com/)

Another definition: Spas are establishments that promote wellness through the provision of therapeutic and other professional services aimed at renewing the body, mind, and spirit (the global Spas economy).

Spa is also defined as an establishment contributing to people wellness in an environment conductive to relaxation offering (Spa finder wellness).

The ISPA further categorizes spas as:

- Day Spa: A spa offering a variety of professionally administered spa services to clients on a day-use basis.

- Destination Spa: A destination spa is a facility with the primary purpose of guiding individual spa-goers to develop healthy habits. This lifestyle transformation can be accomplished by providing a comprehensive program that includes spa services, physical fitness activities, wellness education, healthful cuisine and special interest programming.

- $\quad$ Resort/Hotel Spa: A spa located within a resort or hotel providing professionally administered spa services, fitness and wellness components.

- Club Spa: A facility whose primary purpose is fitness and which offers a variety of professionally administered Spa services on a day use basis (Caribbean Spa and wellness strategy 2014-2018).

Customer Satisfaction: "Customer satisfaction is a term frequently used in marketing. It is a measure of how products and services supplied by a company meet or surpass customer expectation. Customer satisfaction is also defined as "the 
number of customers, or percentage of total customers, whose reported experience with a firm, its products, or its services (ratings) exceeds specified satisfaction goals." (https://en.wikipedia.org/wiki/Customer_satisfaction)

Services quality: Service quality is a focused evaluation that reflects the customer's perception of elements of service such as interaction quality, physical environment quality and outcome quality (Brady and Cronin, 2001). According to Lewis and Booms (1983) service quality is a measure of how well the service level delivered matches the customer's expectation.

Service quality is also defined as the difference between technical quality (what is delivered) and functional quality (how it is delivered) and as process quality (judged during the service) and output quality (judged after the service) (Gronroos, 1983; Lehtinen, 1983). From the above-mentioned review, it seems that service quality is a multi-dimensional concept that means different things to different people (Al-alak 2012).

Previous studies. A number of researchers (e.g. Helmy, E., 1993; Helmy, E., 1993; Rust and Oliver, 1994; Omran, 2000; Kelly and Turley, 2001; Mull et al; 2005; Thelen, S. \& Travers, R., 2007 Egyptian Industrial Modernization Centre (IMC), 2008; Al-alak, 2010) suggested that revealing customer perceptions of service experiences has always been important to the success of service organizations. From a management stand point, managers should systematically examine current services from their customer's perspectives and redesign their service products and environment in which their services are delivered to their target customers. The provision of quality experiences is extremely important for customer satisfaction and retention (Zeithaml et al; 2006). Within the spa industry, offering premium quality, personally tailor-made, and exclusive massage and fitness services is a key contributor to customer satisfaction of spa and wellness programs. The increasing number of publications devoted to such topics as service quality and satisfaction research is a clear testimony to the increased importance of service marketing and management (Howat et al;, 1999; Kelly and Turley, 2001; Ko and Pastore, 2005; Petrick, 2004). Although a substantial amount of research on service quality, satisfaction, and repurchase intention can be found in the marketing literature, little attention has been paid to investigating the impact of service quality perceptions on satisfaction and intention in the spa industry (Al-alak 2012). 


\section{Results}

The demographic profile of customers. The demographic profile of the spa customers is presented in the following table:

Table 3: The demographic profile of spa customers

\begin{tabular}{|l|l|l|}
\hline Gender & Frequency & Percentage \\
\hline Male & 168 & $57.1 \%$ \\
\hline Female & 126 & $42.9 \%$ \\
\hline Total & 294 & $100 \%$ \\
\hline Age & Frequency & Percentage \\
\hline 20 to 40 & 105 & $35.7 \%$ \\
\hline 40 to 60 & 168 & $57.1 \%$ \\
\hline Over 60 years & 21 & $07.2 \%$ \\
\hline Total & 294 & $100 \%$ \\
\hline Nationality & & \\
\hline Europe & Frequency & Percentage \\
\hline America & 105 & $35.7 \%$ \\
\hline Egypt & 21 & $07.2 \%$ \\
\hline Other & 82 & 27.9 \\
\hline Total & 86 & 29.2 \\
\hline
\end{tabular}

There were $57.1 \%$ male customers and $42.9 \%$ female. In terms of age, the percentage of the sample ( $57.1 \%$ ) were from 20 to 40 years of age category, the percentage $(35.7 \%)$ of them had 20 up to 50 years age group, and only $7.2 \%$ had over 60 years. Regarding the nationality of spa customers, the majority of them were from France and the major simple was from Germany (35.7\%). On the other hand, $27.2 \%$ were Egyptian customers and the Arabs were amounted as $29.9 \%$.

The mean and Std. deviation of questionnaire constructs. The means and std. deviations scores of questionnaire constructs are listed in the following table. A five point likert-type scale was used ranging from "1" which meant very poor to "5" very good to measure the quality of products and services, satisfaction, and customer loyalty. 
Table 4: The mean and Std. deviation of questionnaire constructs

\begin{tabular}{|l|l|l|}
\hline Construct & Mean & Std. deviation \\
\hline Product quality & 3.34 & 0.78 \\
\hline Service quality & 3.12 & $\mathbf{0 . 9 0}$ \\
\hline Customer satisfaction & 2.50 & $\mathbf{0 . 6 1}$ \\
\hline Customer loyalty & $\mathbf{2 . 8 2}$ & $\mathbf{0 . 6 2}$ \\
\hline Overall & $\mathbf{2 . 9 4}$ & $\mathbf{0 . 7 2}$ \\
\hline
\end{tabular}

According to the findings, the overall mean score for all statements of the questionnaire were 2.94. In other words, Spa customers mentioned that the quality of products and services were poor, they were not satisfied about that level (2.50), and customers said that they are not loyal to the service provider (2.82).

Regression Analysis This part tries to identify the following impacts:

1. The impact of product and service quality on achieving customers' satisfaction.

2. The impact of customer satisfaction on customer loyalty Then, it will test the hypothesis which states that:

H1. "There is a significant impact (relation) between the quality of products, services and achieving customers' satisfaction.

$\mathrm{H} 2$. "There is a significant impact (relation) between customer satisfaction and customer loyalty.

Regression analysis is used to identify the relationship between variables.

The impact of product and service quality on achieving customers' satisfaction This part tried to identify the impact of product and service quality (independent Variable) on customers' satisfaction (dependent variable).

Table 5: Independent and dependent variables.

\begin{tabular}{|c|c|c|c|c|c|c|}
\hline $\mathbf{R}$ & R Square & $\begin{array}{l}\text { Adjusted-R } \\
\text { Square }\end{array}$ & \multicolumn{4}{|c|}{ Std. Error of the Estimate } \\
\hline 0.854 (a) & 0.729 & 0.727 & \multicolumn{4}{|l|}{0.964} \\
\hline \multicolumn{7}{|l|}{ ANOVA (b) } \\
\hline & $\begin{array}{ll}\text { Sum } & \text { of } \\
\text { Squares } & \\
\end{array}$ & df & $\begin{array}{l}\text { Mean } \\
\text { Square }\end{array}$ & $\mathbf{F}$ & \multicolumn{2}{|c|}{ Sig. } \\
\hline Regression & 726.856 & 2 & 363.428 & 390.763 & \multicolumn{2}{|c|}{\begin{tabular}{|l|}
$0.000(a)$ \\
\end{tabular}} \\
\hline Residual & 270.644 & 291 & 0.930 & & & \\
\hline Total & 997.500 & 293 & & & & \\
\hline \multicolumn{7}{|l|}{ Coefficients(a) } \\
\hline & \multicolumn{2}{|c|}{$\begin{array}{l}\text { Unstandardized } \\
\text { Coefficients } \\
\end{array}$} & \multicolumn{2}{|l|}{$\begin{array}{l}\text { Standardized } \\
\text { Coefficients }\end{array}$} & $\mathbf{t}$ & \multirow[t]{2}{*}{ Sig. } \\
\hline & B & Std. Error & \multicolumn{2}{|l|}{ Beta } & \multirow[b]{2}{*}{978} & \\
\hline (constant) & 1.623 & 0.272 & & & & 0.00 \\
\hline Product quality & 0.041 & \begin{tabular}{|l|}
0.015 \\
\end{tabular} & \multicolumn{2}{|l|}{0.087} & 2.655 & 0.08 \\
\hline Service quality & .555 & 0.022 & \multicolumn{2}{|l|}{0.818} & 24.934 & 0.00 \\
\hline
\end{tabular}

a. Predictors: (Constant), (Service quality, Product quality).

b. Dependent Variable: (Customer satisfaction). 
Table n.5 indicates the reliability of model used in testing the impact of product and service quality on customers' satisfaction. F value was 390.763 with sig. level (0.000). This model indicates the percent of change on customer satisfaction which happened through the quality of product and service. Also it indicates that R-Square was (0.729) which means that the independent variables explain $(72.7 \%)$ of change in the dependent variable.

The impact of customer satisfaction on customer loyalty

Table 6: The impact of customer satisfaction on customer loyalty

\begin{tabular}{|c|c|c|c|c|c|c|}
\hline $\mathbf{R}$ & R Square & $\begin{array}{l}\text { Adjusted-R } \\
\text { Square }\end{array}$ & \multicolumn{4}{|c|}{ Std. Error of the Estimate } \\
\hline 0.489 (a) & 0.240 & 0.237 & \multicolumn{4}{|l|}{2.184} \\
\hline \multicolumn{7}{|l|}{ ANOVA (b) } \\
\hline & $\begin{array}{l}\text { Sum of } \\
\text { Squares }\end{array}$ & df & $\begin{array}{l}\text { Mean } \\
\text { Square }\end{array}$ & $\mathbf{F}$ & \multicolumn{2}{|l|}{ Sig. } \\
\hline Regression & 438.679 & 1 & 438.679 & 91.967 & \multicolumn{2}{|l|}{$0.000(\mathbf{a})$} \\
\hline Residual & 1392.821 & 292 & 4.770 & & & \\
\hline Total & 1831.500 & 293 & & & & \\
\hline \multicolumn{7}{|c|}{\begin{tabular}{|l} 
Coefficients(a) \\
\end{tabular}} \\
\hline & \multicolumn{2}{|c|}{$\begin{array}{l}\text { Unstandardized } \\
\text { Coefficients }\end{array}$} & \multicolumn{2}{|c|}{$\begin{array}{l}\text { Standardized } \\
\text { Coefficients }\end{array}$} & $\mathbf{t}$ & Sig. \\
\hline & B & Std. Error & \multicolumn{2}{|l|}{ Beta } & & \\
\hline (constant) & 6.383 & 0.534 & & & 11.953 & 0.000 \\
\hline $\begin{array}{l}\text { CSs of } \\
\text { employees }\end{array}$ & .663 & 0.069 & 0.489 & & 9.590 & 0.000 \\
\hline
\end{tabular}

The impact of customer satisfaction (independent variable) on customer loyalty (dependent variable

a. Predictors: (Constant), Customer satisfaction.

b. Dependent Variable: Customer loyalty.

The previous table presents the reliability of model used in testing the impact of customer satisfaction on customer loyalty. F value was 91.967 with sig. level (0.000). This model indicated the percent of change on improving customer loyalty in which explained through customer satisfaction. It also indicated that R-Square was (0.24) which means that the independent variables explain (24\%) of change in the dependent variable. 


\section{Conclusions and Ssuggestions}

\section{Research conclusions}

- There were more male customers than female. In terms of age, the percentage of the sample $(57.1 \%)$ were from 20 to 40 years of age category, the percentage $(35.7 \%)$ of them had 20 up to 50 years age group, and only $7.2 \%$ had over 60 years. Regarding the nationality of spa customers, the majority of them were from Europe country $(35.7 \%)$ such as Germany and France. On the other hand, the Arabian customers represent $29 \%$ and $27.2 \%$ were Egyptian customers.

- The majority of Spa customers mentioned that the quality of products and services were poor, they were not satisfied about that level, wish mean that they are not loyal to the service provider. The trust of international clients with regard to the current products offered in some of the wellness facilities is likely to be low.

- At present there are several hotels and resorts as well as day spas claiming to have wellness facilities. The current state of development varies with regard to quality, from excellent to very poor, from renovated to 'in dire need of renovation'. Many of the hotels are lacking an understanding of the clear differentiation between recognized wellness facilities and ubiquitous gym, leisure center, pool or sports club (which international clients would not recognize as spa or wellness tourism facilities).

- There are no comprehensive data available and no organized quality control system in Egypt, possibly due to the lack of a relevant and specialized industry association.

- At present there are only very few national products with regard to the wellness and medical wellness. Such as Nefretari Products (oils, natural soap, lotions and creams).

- Lake of local training programs in wellness products forces a heavy reliance on foreign staff. Many therapists from the wellness sector are foreigners working on a temporary visa basis in current Spa and wellness centers.

\section{Research suggestions}

- Cairo lacks being a model of the Spa city, that model can be found in cities like Luxor, Aswan and Safaga.

- In particular attention should be paid to further develop signature Egyptian spas which will enhance and reinforce Egypt's tourism image. The Cairo Four Seasons Hotel has developed a small wellness center along these lines, with Pharaonic treatments, a Cleopatra milk bath, Nefertari facials and other Egyptian treatments. The Nile Cruise is also a signature tourism product of Egyptian tourism. There is strong potential to develop more elaborate Nile spa cruises. The Oberoi group has piloted this concept and so the Old Cataract hotel in Aswan (insight magazine 2013).

- The women's spa concept should be developed in Cairo to serve its extensive and growing Arab tourism market. Cairo also has potential to develop more high quality city spas in high end hotels. Cairo should develop Aqua parks and day spas using topics as Egyptian Culture and Egyptian Beauty. 
- Cairo is in need to develop professional therapists working at its current and potential spas and health resorts. As the number of spa projects is projected to increase in the coming few years, the two sectors: healthcare and tourism should plan developing human resources in specialized faculties such as faculty of physical education to meet the expected demand. It is worth mentioning that training is very a crucial factor to reach international competencies. Training programs at the university level could help to solve this problem.

\section{References}

- Adams, T.B., 2003. The power of perceptions: measuring wellness in a globally acceptable philosophically consistent way, retrieved from http://www.hedir.org (20.09.08).

- Basheer Abbas Al-alak Ghaleb Awad EL-refae, The Relationships between Service Quality, Satisfaction, and Behavioral Intentions of Malaysian Spa Center Customers, International Journal of Business and Social $\begin{array}{llllll}\text { Science } & \text { Vol. } & 3 & \text { No. } & \text { J } & \text { January }\end{array}$ http://ijbssnet.com/journals/Vol_3_No_1_January_2012/22.pdf

- Caribbean Spa and Wellness Strategy (2014-2018) Prepared by: LCT Consulting \& Associates Ltd July 24th 2013, Available at : http://www.carib-export.com/login/wp-content/uploads/2013/07/Caribbean-Spaand-Wellness-Strategy-2014-2018-Final1.pdf

- Definitions of Wellbeing, Quality of life and Wellness, Posted by Faisal Barwais on Monday, February 28th 2011, available at : http://nwia.idwellness.org/2011/02/28/definitions-of-wellbeing-quality-of-life-andwellness/

- Egyptian Industrial Modernization Centre (IMC). (2008). Egyptian Medical Tourism Strategy. A project conducted by AIT Consulting and sponsored by IMC.

- Erfurt-Cooper, P., Cooper, M., 2009. Health and Wellness Tourism: Spas and Hot Springs. Channel View Publications, Bristol, UK.

- Global Wellness Institute, The Global Wellness Tourism Economy, prepared by SRI International, October 2013. Available at http://www.globalspaandwellnesssummit.org/images/stories/gsws2014/pdf/Global_Wellness_Tourism_Eco nomy_Full_Report_Final.pdf.pagespeed.ce.1e_cNNn2i3.pdf, consulted 6th of October 2014.

- Global Spa Summit, Global Spa Economy 2007, prepared by SRI International, May 2008, Available at : http://www.globalspaandwellnesssummit.org/images/stories/pdf/gss.spa.economy.report.2008.pdf.pagespee d.ce.GkRpJ3hi9E.pdf, consulted 6th of octobre 2014.

- Helmy, E. (2005). Introducing Spas as a New Tourism Product: the Case of Egypt. Egyptian Journal of Tourism Studies, Vol. 4, No.1-2, pp.22-43.

- Helmy, E. (1993). Planning and marketing principles of therapeutic tourism in Egypt, Unpublished M.SC thesis in Tourism Studies, Egypt: Helwan University.

- Hansruedi Mueller and Eveline Lanz Kaufmann (2001), Wellness Tourism: Market analysis of a special health tourism segment and implications for the hotel industry. Research Institute for Leisure and Tourism, University of Berne, Engehaldenstrasse 4, CH-3012 Bern, Switzerland. Available at : file:///C:/Users/soha/Downloads/HEALTH\%20TOURISM\%20SEGMENT.pdf

- Howat, G., Murray, D., \&Crilley, G. (1999). The relationships between service problems perceptions of service quality, satisfaction, and behavioral intentions, Service Quality ,5(2),76-90.

- Harahsheh, S.S., 2002. Curative Tourism in Jordan and its Potential Development. Bournemouth University, United Kingdom.

- International Spa Association (ISPA), http://www.experienceispa.com/spa-goers/spa-101/types-of-spas/

- Joppe, M., 2010. One country's transformation to spa destination: the case of Canada. Journal of Hospitality and Tourism Management 17 (1), 117-126.

- Konu, H., Tuohino, A., Komppula, R., 2010. Lake Wellness - a practical example of a new service development (NSD) concept in tourism industries. Journal of Vacation Marketing 16 (2), 125-139.

- Kisperska-Moro n, D., 2005. Logistics customer service levels in Poland: changes between 1993 and 2001. International Journal of Production Economics 93-94 (8), 121-128.

- La Londe, B.J., Zinszer, P.H., 1976. Customer Service: Meaning and Measurement. National Council of Physical Distribution Management, Chicago. 
- Mohamed, G.A. (2008). Egypt's image as a tourist destination - a perspective of foreign tourists. Tourismos, Vol. 3, No.1, pp.36-65.

- Messerli, H.R., Oyama, Y., 2004. Health and wellness tourism - global. Travel \& Tourism Analyst August, $1-54$.

- Mueller, H., Lanz Kaufmann, E., 2001. Wellness tourism: market analysis of a special health tourism segment and implications for the hotel industry. Journal of Vacation Marketing 7 (1), 5-17. (file:///C:/Users/Dr.\%20Soha\%20Bahgat/Downloads/HEALTH+TOURISM+SEGMENT.pdf)

- Nahrstedt, W., 2004. Wellness: A new perspective for leisure centers, health tourism, and spas in Europe on the global health market. In: Weiermair, K., Mathies, C. (Eds.), The Tourism and Leisure Industry: Shaping the Future. Haworth Hospitality Press, New York, pp. 181-193.

- Omran,Soad 2000.health Tourism: lectures ,6 of October university, Egypt.

- Puczkó, L., Bachvarov, M., 2006. Spa, bath, thermal: what's behind the labels? Journal of Tourism Recreation Research 31 (1), 83-91.

- Smith, M., Puczkó, L. (2009). Health and Wellness Tourism. Butterworth-Heinemann, Oxford, UK.(341344)

- Thelen, S. \& Travers, R. (2007). Identification and Formulation of a sector Strategy for Medical and Therapeutic Tourism in Egypt. Cairo, EUROPEAID for the Egyptian Tourism Authority. 